\title{
Influence of Perceived Socially Responsible Human Resource Management on Task Performance and Social Performance
}

\author{
Danping Shao, Erhua Zhou and Peiran Gao * (D) \\ School of Management, Huazhong University of Science and Technology, Wuhan 430074, China; \\ D201377851@hust.edu.cn (D.S.); iris.zhou@hust.edu.cn (E.Z.) \\ * Correspondence: gaopeiran@hust.edu.cn; Tel.: +86-158-7139-6524
}

Received: 2 May 2019; Accepted: 5 June 2019; Published: 7 June 2019

check for updates

\begin{abstract}
While previous research has already revealed the positive influence of socially responsible human resource management (SRHRM) on organizations, little is known about whether employees' perceived SRHRM can lead to a win-win situation between organization and society. We address this void by examining whether employees' perceived SRHRM can contribute to organizational performance (operationalized as task performance and organizational citizenship behavior, OCB), and social performance (operationalized as volunteering). Using a sample of 314 employee-supervisor dyads from three large manufacturing enterprises in Southeast China, we found that perceived SRHRM could increase employees' OCB and volunteering, but not task performance, through both cognitive (i.e., prosocial identity) and affective (i.e., affective empathy) paths. Furthermore, perceived SRHRM was more positively related to prosocial identity and affective empathy when distributive justice was high. We finally discuss the implications of our findings for both theory and practice.
\end{abstract}

Keywords: socially responsible human resource management; prosocial identity; empathy; organizational citizenship behavior; volunteering

\section{Introduction}

Corporate social responsibility is defined as "context-specific organizational actions and policies that take into account stakeholders' expectations and the triple bottom line of economic, social, and environmental performance" [1]. For several decades, scholars from institution, strategy, marketing, and finance have found the positive effects of corporate social responsibility (CSR) in facilitating legitimacy [2], attracting investors [3], satisfying customers [4] and resolving such broader social problems as climate change, poverty and unemployment [5]. In addition to the tremendous benefits outside organizations, CSR has pronounced influences inside organizations, as demonstrated by many organizational scholars recently. For example, CSR has been shown favorable in enhancing employee performance, satisfaction [6], organizational citizenship behavior (OCB) [7] as well as attracting potential applicants [8] by cultivating high identification [9], providing meaningfulness [10], and signaling social care and justice [11].

Given the abundant benefits of CSR to both society and organization, it is necessary to put CSR into business practices. However, past scholars have mainly investigated the influences and mechanisms of CSR from external perspectives like corporate governance, strategy, and finance, lacking an internal exploration into how CSR practices are carried out in organizations. In addition, most previous studies have focused on the impact of CSR on external stakeholders like consumers, investors and community, ignoring employees' response to CSR. In fact, as the most critical internal stakeholder, employees play a prominent role in embracing and implementing CSR practices. The gaps in current research make practitioners confused and challenged to integrate social goals into business operation effectively. 
To handle this dilemma, several scholars have suggested implementing CSR through progressive HRM practices-the socially responsible human resource management (SRHRM) [12]. Put it simply, SRHRM is a kind of strategic human resources management designed to move CSR into managerial practice by engaging employees [13]. Through the HRM functions like recruitment, training, SRHRM incorporates the idea of social responsibility into organizational daily routines to achieve favorable outcomes. Following this, several scholars have explored the effect of SRHRM. For example, Shen and Benson [13] found that SRHRM had a positive impact on employees' task performance, commitment and extra-role helping behavior.

While these findings have deepened our understanding of SRHRM, several urgent questions need to be further explored. First, as policies and practices implementing CSR, can SRHRM translate social problems into business interest successfully? That is, whether SRHRM can strike a balance between social performance and organizational performance and thus create a win-win situation between organization and society? However, existing research has just examined and demonstrated the positive effects of SRHRM on employees' organizational performance, lacking an investigation into the impact of SRHRM on employees' social performance. Second, how does SRHRM engage employees in the CSR practices? More specifically, how do organization guide employees to care for others and contribute to broad society? Previous studies have explained the underlying mechanism of SRHRM mainly from a cognitive perspective, such as organizational identification theory [13] or organizational commitment [14], ignoring the possible effect of emotional factors. As such, an integrative and in-depth perspective is needed to unveil the underlying mechanism of SRHRM comprehensively. Third, what is the boundary condition to bring SRHRM into work? Scholars from justice and CSR domain have historically noted a prominent effect of justice on CSR since they share a common fundamentally ethical foundation $[2,15,16]$. Especially the distributive justice, concerned with distributive norms of reward [17], may stand out as a salient issue in the resource allocation involved in SRHRM. Scholar has yet to examine the possibly contingent effect of distributive justice on SRHRM.

To advance theory, research, and practice, we seek to answer these questions by developing a framework explaining how employees' perceived SRHRM affects employees' organizational performance (operationalized as task performance and $\mathrm{OCB}$ ) and social performance (operationalized as volunteering). Our research makes several primary contributions. Firstly, although SRHRM is a set of practices aimed at striking a balance between organization and society, no existing research has yet to examine the relationship between SRHRM and organizational performance as well as social performance. To address this gap, we extend the SRHRM literature by simultaneously examining the possible effects of SRHRM on both employees' organizational performance and social performance. Secondly, little prior research has partially explained the underlying mechanism of SRHRM with mere cognitive perspective or affective perspective, lacking an integrated framework. Given that, we adopted a dual model to explain the influence of SRHRM on performance by integrating identity theory [18,19] and affect event theory [20]. Particularly, we proposed and found that prosocial identity served as a cognitive mechanism and empathy served as an affective mechanism mediating the relationship between SRHRM and employee outcomes. Thirdly, previous research has mainly focused on contextual factors such as POS and cooperative climate [13] when identifying the boundary factors of the influence of SRHRM. As such, our work has introduced and demonstrated a more vitally related issue, the distributive justice, as the moderating factor of the effect of SRHRM. Taken together, the current research has shed light on whether, why and under what circumstances SRHRMR can create a win-win situation between both organization and society. The result has confirmed that SRHRM can serve as a favorable tool to create a win-win situation between organization and society. This not only advances our understanding about SRHRM, but also inspires the implementation of CSR values in practices, which in turn promotes the sustainable development for both organization and society. 


\section{Theory and Hypothesis Development}

\subsection{SRHRM}

SRHRM was first introduced theoretically by Swanson [12] as a response to the challenge of translating corporate social responsibility (CSR) into business practices. It is a set of HRM practices embedded with the idea of social responsibility. For instance, it involves hiring employees who exhibit relatively high cognitive moral development and show the personality trait of agreeableness; formulating appraisal criteria based on economic and social performance; designing pay systems that reward economic and social performance; developing employee skills receptive to stakeholder engagement and communication.

Three critical components of SRHRM should be noted. First, SRHRM is a kind of strategic human resource management like selective hiring, extensive training, performance appraisal, and compensation [21]. At its essence, it is a tool to implement CSR. Second, SRHRM aims at striking a balance between organizational and social performance. Distinct from high-performance work system (HPWS) which mainly pursues competitive advantages, SRHRM not only cares about organizational outcomes but also concerns broader social welfare. Third, SRHRM achieves its goal by engaging employees in the process of CSR implementation [22]. For example, it develops employees' knowledge, skills, abilities and enhances employees' motivation to participating in the activities delivering social responsibility by providing training and contingent rewards.

\subsection{Dual Mechanisms of SRHRM on Employees' Performance}

Since the conception of CSR was introduced, the link between CSR and performance has long been heatedly debated by numerous scholars from various areas with diverse perspectives. Generally speaking, earlier researchers mainly explained the underlying mechanism between CSR and performance primarily from corporate governance channels or compensation incentive channels at the macro level. For example, Hong et al. [23] have found that firms with more shareholder-friendly corporate governance are more likely to provide compensation to executives linked to firm social performance outcomes. Similarly, Ikram et al. [24] have demonstrated that firms can signal firmer commitment to CSR and increase firm value by tying executive compensation to CSR, but the nature of the CSR contract matters. Particularly, compared to Transparent CSR contracts that clearly define the relationship between executive pay and CSR-related milestones, Opaque CSR contracts correlate more strongly with measures of good governance and firm value. Recently, with ongoing calling for the implementation of CSR initiative, more and more studies have turned to unveil the association between CSR and performance from the psychological channels, so as to provide more useful guidance for the translation of CSR values into practices. Consistent with this trend, our work aims at exploring the relationship between SRHRM and employees' performance from the psychological channel at the micro level.

Psychological scholars have distinguished between two motives which are provoked by work situation and then influence subsequent attitudes and behaviors, the cognitive motive and affective motive [25]. A cognitive motive means that the individual is guided by the expected probabilities of obtaining desired outcomes, along with their associated costs and benefits [26]. In contrast, an affective motive represents that actors are driven by affective state, which is more automatic, impulsive [27].

Given this, we extend this duality to SRHRM literature and propose that SRHRM influences organizational and social performance through both cognitive path and affective path. In short, prosocial identity is used to represent the cognitive pathway, explaining employees' response to SRHRM based on the cognitive judgment. Whereas empathy represents the emotional pathway, explaining employees' response to SRHRM driven by an emotional factor.

Taken together, integrating identity theory $[8,18,19]$ and affective event theory [20], we identify two potential mediating mechanisms linking perceived SRHRM to performance: The cognitive path (i.e., prosocial identity) and affective path (i.e., empathy). Moreover, we examine the effect of distributive 
justice as a moderator on the influence of SRHRM. We test our hypothesis with multisource data and discuss implications for theory and research on SRHRM, identity construction, strategic human resource management. Our overall conceptual model encompassing a moderator and two mediators is presented in Figure 1.

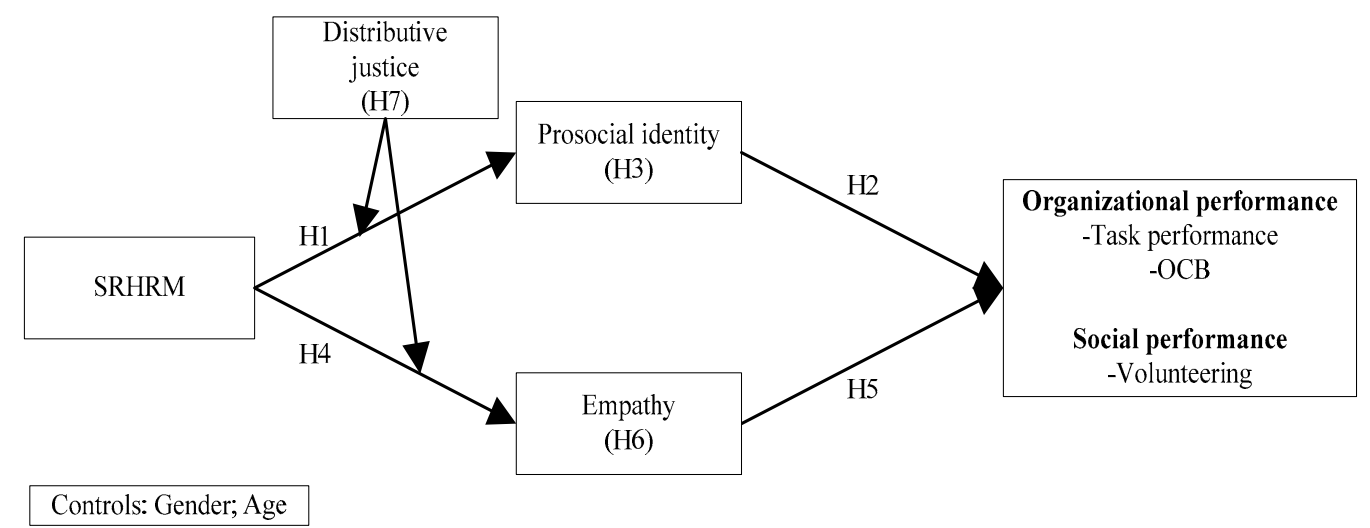

Figure 1. Proposed conceptual model of the relationship between socially responsible human resource management (SRHRM) and employee organizational and social performance.

\subsubsection{Cognitive Path: The Mediating Role of Prosocial Identity}

Identity refers to a self-referential or self-defining description answering the question "who am I?" or "who are we?", including social identity and personal identity. The former is based on social collectives such as nations, organizations and occupations while the latter is based on personal attributes such as abilities, interests [28-30]. Prior scholars have claimed that people will establish, maintain, or refine a contextually appropriate identity to locate himself or herself within an organizational context [31]. Moreover, efforts people creating new identities are influenced by situational events that challenge one's sense of self [32]. Just as Dutton, Roberts and Bednar [18] noted "changes in the context or situation encourage the creation of new identity content or possible selves."

As such, organizations, as people's main life domain, may play an essential role in shaping and cultivating people's new identities with its continually updated practices and systems. Similarly, employees, on the other hand, may form, transform and modify identities to achieve a better fit with work demands. In line with this logic, Ashforth and his colleagues $[8,28]$ have developed a framework modeling the process of how an individual defines who he or she is, namely the identity construction process. Three critical elements have been identified during the process: Sensebreaking, sensegiving and sensemaking. Sensebreaking is the destruction or breaking down of meaning [33] while sensegiving is an attempt to guide the meaning construction of others toward a preferred redefinition of organizational reality. Sensemaking, on the other hand, is a process individual interprets internal and environmental cues [32]. In general, organizations set the stage for an individual to construct their identities through sensebreaking, rendering individuals more receptive to organizational cues conveyed by sensegiving. Finally, the individual utilizes sensemaking to construe their identity.

SRHRM, as a new form of HRM practice advancing social betterment, may cultivate employees' caring self, particularly the prosocial identity in this context. Prosocial identity is defined as the component of the self-concept concerned with helping and contributing [34,35]. It should be highlighted that prosocial identity here refers to the social identity shaped and shared by organization members. Researchers have contended that although people may hold prosocial identities, the salience of the identities depends on situational cues [36]. Based on the literature on identity theory and identity construction model, we will demonstrate explicitly how SRHRM shapes employees' prosocial identity below.

First, SRHRM conveys caring and contributing values into employees' sense of self by sensebreaking and sensegiving. For example, the organization will consider applicants' interest 
and capability in CSR activities in recruitment and staffing. Moreover, SRHRM provides training programs to cultivate CSR knowledge and skills. This would signal employees the importance of CSR to organization. In addition to guidance in internal perception, SRHRM further strengthens CSR value and meaning through external incentives such as linking promotion, compensation, assessment to their performance in CSR activities. On the one hand, policies of sensebreaking will challenge employees' current belief about what their work is and who they are and then stimulate them to search for how things work and what is expected. On the other hand, the policies of sensegiving convince employees to believe that their work makes a difference to the betterment of the world. Moreover, contributing to the social betterment makes them a caring and helping man.

By doing so, the organization creates an environment for employees to question what is unfolding around them and then prompt them to seek identity-relevant information [33]. The connection between sensemaking and identity construction is relatively well established [8,32]. As pointed out by previous scholars, identity is often the target of sensemaking [32], and sensemaking is accordingly tied to identity motives [37]. Notably, it is a social process to build up a new identity through sensemaking. Firstly, just as some researchers have highlighted, "although sensemaking facilitates identity construction, the process is recursive; a budding identity shapes sensemaking" [28]. That is, sensemaking facilitates identity construction and the newly built identity, in turn, shapes the way how people perceive the environment. Employees ultimately build up stable views of themselves during the recursive interaction between employees and the organizational environment. Secondly, the process of identity construction through sensemaking involves the social observation and interaction among employees [37]. That is, employees interpret the environment based on what their peers do and what their peers say. Through repeated interaction and communication, employees form stable perceptions and opinions about themselves explicitly or implicitly. In short, organizations first set the stage with sensebreaking and sensegiving, employees then build up the new prosocial identity through sensemaking [38]. Indeed, scholars from corporate governance domain have recently found that corporate social responsibility and corporate governance (CG) interact to influence a firm's intellectual capital (IC) efficiency, which leads to trust between people, the reputation of the organization, and the development of a corporate identity [39]. Therefore, we posit that:

\section{Hypothesis 1 (H1). Perceived SRHRM is positively related to prosocial identity.}

The self-verification theory argues that people are motivated to verify, validate and sustain their existing self-concepts [40,41]. The consistency between action and self-concepts offers people a crucial source of coherence. The coherence serves as an invaluable means of defining their existence, organizing experience, predicting future events, and guiding social interaction [42]. In other words, people tend to express in words and in acting one's important values to identifying oneself" [43]. According to Leary [44], self-verification processes seem to influence behaviors in three ways. First, self-verification leads people to interact with those who confirm their self-concepts. Second, people tend to behave in ways that elicit self-verifying feedbacks from others. Third, people look for and remember information that verifies their views of themselves. Given that, we expect that prosocial identity, as has been mentioned before, which is the helping and contributing component of the self-concept, would influence employees' task performance and OCB through self-verification process.

Our core assumption is that, when a person views himself or herself as a prosocial person, he or she will be willing to express this self through engagement in activities reflecting responsibility and care, which will improve their performance. First, prosocial employees would be more likely to interpret their work situation in a caring and responsible way. Then, they may behave in such a way to get feedbacks consistent with their prosocial identity. Third, in the context of SRHRM, employees should be more likely to cooperate with coworkers around since they share the same collective identity, the prosocial identity. In this way, trust and cooperation are easy to be built up within the organization. Therefore, the way of interpretation, action and interaction with others caused by the self-verification 
would change employees' understanding about their work roles, demands, expectations and thus promote their task performance and OCB.

As for the task performance, evidence has shown indeed that one's helping such as prosocial behaviors will foster interpersonal harmony, facilitate task completion, build and maintain relationships [45-47], which is directly or indirectly beneficial to task performance. Similarly, studies in altruism suggest that the value of concerning for others makes people more acceptable to social information and feedbacks without carefully weighing its consequences, leading to improvement in performance [48].

As for the $\mathrm{OCB}$, it has been assumed that people holding prosocial identity would be more sensitive to others' needs and more likely to go above and beyond their required tasks to help others regardless of rewards, like OCBs in the workplace $[49,50]$. This perspective is consistent with Rioux and Penners's [51] observation that employee's desire to help and connect with others was strongly related to supervisor-rated OCB in the form of altruism and peer-rated OCB in the form of altruism and civic virtue. Following this, researchers further found that citizen role identity served as the indirect mediator between motives and OCBs. In other words, when employees internalize citizenship behaviors into their identities, they may be motivated to perform OCB to sustain as good citizens. Taking the arguments and evidences above together, we propose that:

Hypothesis 2 (H2). Prosocial identity is positively related to task performance (2a) and OCB (2b).

Hypothesis 3 (H3). Prosocial identity mediates the positive relationship between perceived SRHRM and task performance (3a) and OCB (3b).

Social performance is a general evaluation of the contribution an organization makes to broader society [52-54]. With the recent advancement in CSR initiatives, various ways have been adopted for organizations to contribute to society, like charitable giving, environment protection, community service and volunteering. Volunteering, defined as giving time or skills during a planned activity for a volunteer group or organization, is a popular way for organizations to embrace CSR [10,55]. For example, employees participate in a post-disaster reconstruction, or teach immigrant kids native languages during a corporate volunteer day. As illustrated by the examples, volunteering here refers to an important vehicle for organizations to contribute to society through the engagement of employee. We choose volunteering as the representative of social performance for two reasons.

First, volunteering is one of the most widely popular forms of CSR, embraced by both the organization and employees. Over 90 percent of Fortune 500 companies have formally sponsored and subsidized employees' efforts to perform community service and outreach activities on company time [56]. To organization, volunteering is a desirable choice to exert broadly and positively social impacts [55] and thus gain reputation [56] and competitiveness [57] as it involves multiple stakeholders, like the nongovernmental organizations (NGOs), target groups and internal employees. To employees, participation in volunteering is an excellent chance to enrich their work life, craft professional skills and promote work meaningfulness [58]. Just as Caligiuri and his colleagues [58] have found, volunteering created a win-win-win situation for organization, target group, and employees. Second, the implementation of volunteering program requires employee engagement. That is, volunteering takes an employee-centered perspective of CSR, rather than an up-down perspective such as charitable donations made by executives and managers [59]. Specifically, volunteering is a planned activity and not a spontaneous act of helping. Thus, it is the time and skills, but not simply financial donations, that employees should offer. To this end, human resource management is supposed to align organizational goal, employees' participation as well as the social cause together.

Following this, we argue that SRHRM will encourage volunteering through shaping employees' prosocial identity. What the three has in common is the underlying idea of responsibility and the concern for others. We will focus on unveiling the process how SRHRM spreads the responsible and caring idea through cultivating employees' prosocial identity and then engaging them in volunteering. 
As has been mentioned before, SRHRM plays a significant role in delivering the idea of helping and concerning for people in a broader society with human resource management. For example, with the recruitment system, SRHRM hires new employees who are more likely to help others in need, like, with previous experience in volunteering. With the training and development system, SRHRM can share and communicate the prosocial value of CSR among employees. With the evaluation system, SRHRM sets CSR performance indicators and monitors results to performance objectives. Moreover, SRHRM provides opportunities for employees to carry out this value, such as volunteering. These efforts together enhance increase employees' sensitivity and readiness to incorporate the idea of care and responsibility into their self-perception and then their wok life.

According to self-verification theory [60] mentioned above, when people perceive themselves as a prosocial person, they will perform on a task or job in a manner to verify their prosocial selves. Then, it may be an appropriate way to express prosocial selves in volunteering programs such as community safety, neighborhood schools, and natural environment protection. Indeed, scholars in volunteering domain have found that volunteering can satisfy people's desire for meaningfulness, or the "value fulfillment [61]". That is, volunteering was a way to act on what a person values and an outlet to do something they perceive as worthwhile [10,58,62,63]. Just as Grant, Dutton and Rosso [35] have observed that when employees volunteer to contribute to others in need, they perceive themselves as more caring, compassionate, and worthy individuals. Thus, we posit that:

Hypothesis 2c (H2c). Prosocial identity is positively related to volunteering.

Hypothesis 3c (H3c). Prosocial identity mediates the positive relationship between perceived SRHRM and volunteering.

\subsubsection{Affective Path: The Mediating Role of Empathy}

Affect, encompassing emotion and mood, has long been recognized as vital factors influencing employees' attitudes and actions in an organization context. In comparison, mood is relatively weaker, more stable and longer lasting without certain origins whereas emotions are more intense, shorter duration and related to a specific object $[64,65]$. For example, people may be in a happy mood without any reasons for a week and feel angry for being criticized by the supervisor. Scholars have called for more research on the emotions since emotions, as the result of different events, have specific targets and produce different outcomes [20].

As a favorite topic in psychology and organizational behavior domain, empathy is defined as an other-oriented emotion aroused in response to the needs of others that elicits caretaking behavior [66]. It has two distinguishable but related dimensions: Perspective taking and empathic concern. Perspective taking is the tendency to be aware of and adopt the perspective of the other (cognitive empathy) whereas empathic concern is the tendency to respond emotionally to the fortunes and misfortunes of others (affective empathy) $[67,68]$. In this research, we focus on employees' emotive reaction aroused in the SRHRM and its subsequent influence.

Affective event theory (AET) serves as a powerful framework to explain the role of emotion in work setting, describing the emotion arises from the work event and then influence people's performance-related behaviors [20]. According to AET [20], affective events are defined merely as "a change in circumstances, a change in what one is currently experiencing" [20]. Moreover, specific events at work generate specific emotions, like happiness arises when one has reached a goal whereas sadness arises when one faces a loss. AET further posits that individuals affect stems from appraisals of affective events in the work environment. In other words, it is not an event itself that gives rise to emotions but how events are interpreted by the people [69]. From a perspective of evolutionary psychology, Goetz and his colleagues [70] have argued that people make a cost-benefit calculation in the responding of empathic situation. As for the benefit aspect, people evaluate whether it is 
self-relevant and deserving. Whereas as for the cost aspect, people evaluate their level of resources to be compassionate. Following this, Atkins and Parker [69] later proposed a comprehensive model identifying three critical appraisals to depict the formation process of compassion. The first appraisal is if the event is self-relevant. The second appraisal is whether the event is worthy of one's help. The final appraisal is whether one can cope with the event and bring about the desired outcomes. All of the three appraisals are required to arouse empathic emotion.

Grounded in the AET literature, we connect SRHRM and empathy to expect that SRHRM will serve as an affect-inducing event invoking employees' empathy. We will explicate the process explicitly how SRHRM elicits employees' empathy through influence their interpretation about organizational HRM practices. First, SRHRM enables employees to understand CSR as self-relevant by aligning the CSR mission, value and influences with employees' work. For example, an employee in the food industry will know his or her work plays a significant role in other's health. Whereas an employee in the auto industry will know his or her job influences other's safety and energy consumption. People will be connected to the anonymous others outside the organization in the SRHRM training program, in which influences of one's work are acknowledged to people. When employees are aware of the influences of their work on others' lives, they will be more likely to seek to make a positive difference in their work $[48,62]$.

Second, SRHRM makes employees believe that organizational CSR initiatives deserve their efforts. For instance, SRHRM can motivate employees by delivering a responsible culture to make the employee feel proud and meaningful to be members of a responsible organization. On the other hand, the material incentives for employees' performance in the CSR practices, can also trigger employees' motivation to respond positively to SRHRM practices. With both the tangible and intangible rewards, the SRHRM practice can win employees' support and then engender their positively attitudinal, emotional response, like empathy.

Third, SRHRM promotes employees' "coping self-efficacy" by providing related resources and skill training, such as how to develop more environment-friendly products, how to communicate with stakeholders [69]. Self-efficacy refers to one's belief in one's capability to perform a specific task [71]. It determines whether coping behavior will be initiated, how much effort will be expended, and how long it will be sustained facing obstacles and aversive experiences [72]. When an employee knows how to improve his or her work to impact others positively, such as more environmental-friendly product, more safe food, he or she will obtain more "coping self-efficacy" and be more likely to make positive difference. After the three appraisals of SRHRM practices above, employees may support, trust and accept the caring value preached by SRHRM practices and then feel empathic for others in need. Accordingly, we hypothesize that:

\section{Hypothesis 4 (H4). Perceived SRHRM is positively related to empathy.}

After describing how specific events generate specific emotional reactions, AET goes on to indicate that these emotions, in turn, translate to spontaneous, affectively driven behaviors at work [20,73]. Within this conceptual framework, behaviors most directly influenced by discrete events are those that are more closely related to affective states, or what Weiss and Cropanzano [20] called "affect-driven behaviors." As such, empathy may motivate employees to engage in a number of actions that are prosocial in nature. Indeed, extensive research in social psychology has suggested empathy as one of the most important motivations for altruistic behavior $[36,67,74,75]$. For example, Omdahl and O'Donnell [76] pointed out that individuals experiencing empathic emotion tended to "catch" the needs of others and lead to action tendencies aimed at reparative behaviors, such as altruism and helping. As in the workplace, people driven by empathic emotion may be sensitive to the needs of proximate others like coworkers and thus perform more OCB. Organizational researchers have already paid attention to the role of empathy in predicting OCB. For example, Settoon and Mossholder [77] have predicted, and found that empathic concern served as a mediator between relationship quality variables 
and person-focused ICB whereas Joireman and his colleagues [78] have noted those who are high in empathy and adopt a long-term horizon tend to engage in OCB more.

Apart from the facilitation of OCB, empathy invoked by SRHRM may also contribute to the task performance either directly or indirectly. Since the positive emotion such as empathy caused by SRHRM drives people to see situations from another's perspective more easily, cooperate more, are more open to information, share information more readily, and is kinder to others $[79,80]$. Therefore, we hypothesize that:

Hypothesis 5 (H5). Empathy is positively related to task performance (H5a) and OCB (H5b).

Hypothesis 6 (H6). Empathy mediates the positive relationship between perceived SRHRM and task performance (H6a) and $\mathrm{OCB}(\mathrm{H} 6 b)$.

As has discussed above, volunteering is such a kind of activities aimed at exhibiting compassion and concern for people outside the boundaries of organizations $[2,81]$. Thus, it is a widespread and predominant approach for an organization to address societal concerns ranging from environment protection to closing the wealth gap and to educational inequity. In addition to its significant benefits to broader society, evidence has also shown its remarkable role in maintaining good reputation [82], attracting and recruiting qualified applicants, building skills, enhancing meaningfulness, and promoting pride and retention inside organization $[10,57,58,83]$.

As such, there is an ongoing interest in exploring what motivates and sustains long-term active participation in voluntary associations. While the antecedents motivate of volunteering is rich, the altruistic motive stands out as a prominent and predictive factor. The altruistic motive behind volunteering is often referred to as "warm glow" feelings which captures the emotion connected with prosocial helping behavior, a feeling that in itself is motivating [84]. As such, empathy, as a kind of emotion conveying caring and concern to others outside the organization, may give rise to employees' participation in volunteering. Indeed, it has long been demonstrated that people experiencing empathic emotion are likely to engage in the altruistic behavior such as OCB inside organization [85] and volunteering outside the organization [57].

Similarly, several scholars have demonstrated that individuals with higher empathy, emotional stability were more receptive to volunteering participation [86]. In line with this argument, Craig-Lees, Harris and Lau [57] have empirically demonstrated that empathy was a vital factor to motivate and sustain long-term active participation in volunteering. Here, we assume that as a more direct way of helping and caring, empathy will motivate employees in the volunteering initiatives. Therefore, we hypothesize that:

Hypothesis 5c (H5c). Empathy is positively related to volunteering.

Hypothesis 6c (H6c). Empathy mediates the positive relationship between perceived SRHRM and volunteering.

\subsection{Moderation of Distributive Justice}

It has long been recognized that corporate social responsibility (CSR) and organizational justice share a common fundamental ethical assumption of normative treatment $[2,16,87,88]$. Particularly, CSR implies norms with regard to the fair treatment of individuals or environments external to the organization. Whereas justice entails norms regarding the fair treatment of individuals within the organization. Just as Aguilera and her colleagues [2] described, corporate social responsibility could be seen as a kind of social justice. As such, we expect the perceived SRHRM, an organizational effort to convey fair treatment to people outside organization may draw employees' attention to the justice treatment of themselves. 
Organizational justice, defined as employees' perceptions of fairness in their employment relationship [89], plays a significant role in employees' outcomes [90]. So far, scholars have identified several dimensions of justice: Distributive justice (relating to the fair distribution of resources, roles, and responsibilities), procedural justice (fairness in decision making), informational justice (justification of decisions), and interpersonal justice (fairness in interpersonal relationships). It is possible that all of these aspects may be prevalent in the implementation of SRHRM practices. For example, a decision concerning a fair investment to a social cause (distributive justice) should be carried out in a fair process (procedural justice), during which information should be delivered fairly to everyone (informational justice, interpersonal justice). Particularly, we focus on distributive justice, which refers to employees' evaluations of the fairness of outcomes [91]. Previous research has pointed out that distributive justice may make employees more sensitive to resource, cost and investment [92]. In the context of SRHRM, the cost and resources distribution involved may draw much more attention of employees to the organizational practices making investments to others outside the organization. That is, distributive justice perception may amplify the effects of SRHRM. Therefore, we expect a moderation effect of distributive justice on the relationship between the SRHRM and employee outcomes.

Specially, we first expect that distributive justice perception will strengthen the positive effect of SRHRM on prosocial identity and emotion. One of the reasons is that fair treatment signals to members that all members of a group are valued and respected [93]. The second explanation may be that fairness perception makes management policies more trustworthy, non-biased and legitimate. Furthermore, fair treatment enables employees to reciprocate with positive work attitudes and behaviors to contribute to organizational goals [94]. As in the case of SRHRM, employees are expected to react more positively to such practice and policies when they believe they are treated fairly. That is, when SRHRM is coupled with high distributive justice, employees are more likely to react positively to the organizational practices.

Justice perception makes people more acceptable to organizational policies and values, whereas injustice may shape negative cognitions, emotions, attitudes and behaviors [92]. Indeed, scholars have demonstrated that low justice perception would bring about unfavorable response, such as job dissatisfaction, intent to turnover [95], post-complaint behavior [96], theft [97], sabotage [98] or even organizational retaliatory behaviors [99]. With low distributive justice perception, employees may be less likely to trust organizational policies. As such, they may conceive SRHRM as less trustworthy and reliable. Further, scholars in the CSR domain have found that organizational justice emerges as an essential factor influencing employees' judgment of the CSR authenticity [100]. That is, how fairly employees are treated may affect employees' assessments and responses to organizational practices addressing a fair treatment to others outside organizations. More particularly, when employees themselves are experiencing low distributive justice, they may be more likely to doubt the authenticity of SRHRM practices which promote fair treatment and caring for others. As such, distributive justice may weaken the influence of SRHRM on prosocial identity and empathy. Therefore, we hypothesize that:

Hypothesis $7 \mathbf{a} \mathbf{( H 7 a )}$. The relationship between perceived SRHRM and prosocial identity is stronger when distributive justice is high.

Hypothesis $7 \mathbf{b} \mathbf{( H 7 b ) . ~ T h e ~ r e l a t i o n s h i p ~ b e t w e e n ~ p e r c e i v e d ~ S R H R M ~ a n d ~ e m p a t h y ~ i s ~ s t r o n g e r ~ w h e n ~ d i s t r i b u t i v e ~}$ justice is high.

\section{Methods}

\subsection{Sample and Procedure}

We test our hypothesis using 314 employee-supervisor dyads data. We first contacted the leaders through Business School graduate student contacts. To make sure the representativeness of the samples, we consider the following factors when selecting the enterprises. First, we checked the company 
websites and communicated with leaders to make sure the company has established the HRM practices concerning CSR. Second, the enterprise whose primary business is not closely related to corporate social responsibility is not considered. Third, companies with less than 500 employees are not considered, as they may not have sufficient resources to build up SRHRM. Finally, three large enterprises in Southeast China were chosen as our research samples.

We collected data from the three enterprises with the same procedure. We first communicated with the human resource managers about the goal of our research, the detailed operation process and the help we expected from them, such as identifying line managers who can participate in the research. Then human resource managers would connect the line managers, ask them to select randomly 1-4 subordinates who can participate in this research and provide the list of their names. In addition, the line managers were asked to evaluate the selected employees' performance in the supervisor questionnaire. After that, we would get a list of all employees who could participate in the survey. In addition, with the support of human resource managers, all the participants were convened in a conference room. We provide a detailed description of the study, as well as the intended use of the results, to participants at the all-employee company meeting. All the participants gave their written free consent. Finally, we distributed a total of 400 questionnaires to 112 line managers.

Employees provided data for their demographic variables, the SRHRM, prosocial identity and distributive justice whereas their supervisor was asked to rate their subordinates' task performance, $\mathrm{OCB}$ and volunteering. We assigned an identification number to each questionnaire in order to match subordinates with evaluations of their supervisors. We also provide an envelope with seal tape for participants to seal the finished questionnaire to ensure confidentiality of their response. Participants completed the survey voluntarily and anonymously. After completing the survey, each participant was given a small gift as an incentive. All of these procedures were conducted by the ethical standards of the Declaration of Helsinki. This study was reviewed and approved by the Human Research Ethics Committee (HREC) at the HuaZhong University of science and technology.

Finally, we received 314 useful questionnaires from 105 line managers and their 314 employees, for a response rate of $78.5 \%$. Among the 314 employees, $51.6 \%$ are men, $48.4 \%$ are women. In terms of age, $74.7 \%$ were aged 30 or below, $24 \%$ were aged between 30 and $40,1.3 \%$ were aged 40 or above. Regarding education, $10.5 \%$ finished their high school, $61.5 \%$ finished their college degrees, $28.1 \%$ held a bachelor or above degrees.

\subsection{Measure}

We created Chinese versions for all measures following the commonly used translation-back translation procedure. All the measures use the same response scale, ranging from 1 (strongly disagree) to 7 (strongly agree).

SRHRM is a kind of strategic human resources management designed to move CSR into managerial practice by engaging employees [13]. It was measured using the 6-item scale developed by Shen and Benson [13]. A sample item was "my company provides adequate CSR training to promote CSR as a core organizational value." The Cronbach's alpha was 0.90 .

Prosocial identity is defined as the component of the self-concept concerned with helping and contributing [34,35]. It was measured using the 3-item scale developed by Grant et al. [35]. A sample item was "I see myself as caring." The Cronbach's alpha was 0.832.

Task performance encompasses behavior that bears directly on an organization's technical core [101]. It was measured using the 5-item scale developed by Williams and Anderson [102]. A sample item was "adequately complete assigned duties." The Cronbach's alpha was 0.863 .

OCB is defined as contributions to the maintenance and enhancement of the social and psychological context that support task performance. It was measured using the 9-item scale developed by Farh et al. [103] which is developed and validated in China. A sample item was "Initiates assistance to coworkers who have a heavy workload." The Cronbach's alpha was 0.842 . 
Empathy is defined as an other-oriented emotion aroused in response to the needs of others that elicits caretaking behavior [66]. It was measured with six items from the Interpersonal Reactivity Index (IRI) [68]. A sample item was "I often have tender concerned feelings for people less fortunate than me." The Cronbach's alpha was 0.822 .

Distributive justice refers to the fairness of decision outcomes, and individuals judge it by determining whether the perceived ratio of outcomes to inputs matches those of a comparison other, or whether resource allocations match appropriate norms [104]. It was evaluated using the 4-item scale developed by Colquitt [105]. A sample item was "Does your (outcome) reflect the effort you have put into your work?" The Cronbach's alpha was 0.918 .

Volunteering is defined as giving time or skills during a planned activity for a volunteer group or organization [10]. It was evaluated using the 5-item scale developed by Rodell [10]. A sample item was "this employee gives his/her time to help a volunteer group." The Cronbach's alpha was 0.906.

It should be noted that, in our research, volunteering serves as a kind of employees' social performance linked to their promotion, compensation, just like task performance and OCB. Despite that, volunteering is employees' activities outside the organization, the organizing, planning and implementation are carried out inside the organization. Supervisors may be responsible for motivating employees, allocating resources and tasks [106] and evaluating performance in organizational volunteering programs. Therefore, employees' performance in volunteering were measured by their supervisor in our research.

Control variables. Our conceptual model includes two control variables: Employee age and gender. In addition, notably, when it comes to understanding the true relationship between organizational phenomena and performance, the endogeneity problem occurs [107]. That is, the dependent variables and independent variables can all be determined by some other variables, such as firm size.

One technique commonly used to mitigate endogeneity issues is to control the third factors (e.g., firm size) in organizational behavior (OB) domain. For example, firm size serves as an important factor affecting SRHRM and performance simultaneously. According to previous studies, we can control the firm size measured by total assets, total sales, and market capitalization [108]. However, considering the complex theoretical sampling strategy, all the three organizations in our sample have more than 500 employees, which weakening the effect of firm size on SRHRM and performance. Therefore, only employee age and gender were controlled as they might exert more influence potentially on employees' interpretation of and responses to organizational policies, task performance, and OCB and volunteering $[109,110]$.

\subsection{Analytic Strategy}

We first conducted CFAs to evaluate the discriminant validity of the key variables. Then, we tested our hypotheses via structural equation modeling (SEM) analysis using the Mplus 7 software package with all the latent variables indicated by their observed items. SEM analysis allowed us to test the effects of independents, mediator, and moderator variables simultaneously in the context of comprehensive models, as suggested by Edwards and Lambert [111]. Specifically, the direct effects of SRHRM on the three performance outcomes and mediator were tested by the structural equation analysis. As for testing the indirect effects, the Monte Carlo method simulation computed 95\% confidence intervals ware applied. To model the interactions with latent variables, we used the latent moderated structural equation approach [112]. This approach provides unbiased estimates of interaction effects between latent variables that are corrected for measurement error.

\section{Results}

Table 1 reports the means, standard deviations, and correlations among the variables.

Consistent with our predictions, SRHRM was positively correlated with prosocial identity $(r=0.39$, $p<0.01)$, empathy $(r=0.43, p<0.01)$. Prosocial identity was positively correlated with OCB $(r=0.33$, 
$p<0.01)$ and volunteering $(\mathrm{r}=0.28, p<0.01)$. Empathy was positively correlated with task performance $(\mathrm{r}=0.14, p<0.05)$, OCB $(\mathrm{r}=0.28, p<0.01)$ and volunteering $(\mathrm{r}=0.28, p<0.01)$.

Table 1. Means, standard deviances and correlations among variables.

\begin{tabular}{ccccccccccc}
\hline Variable & $\mathbf{M}$ & SD & $\mathbf{1}$ & $\mathbf{2}$ & $\mathbf{3}$ & $\mathbf{4}$ & $\mathbf{5}$ & $\mathbf{6}$ & $\mathbf{7}$ & $\mathbf{8}$ \\
\hline 1. gender & 1.48 & 0.50 & & & & & & & & \\
2. age & 28.72 & 3.87 & -0.03 & & & & & & & \\
3.SRHRM & 5.23 & 1.08 & $0.17^{* *}$ & 0.08 & & & & & \\
4.identity & 5.95 & 0.79 & 0.06 & 0.04 & $0.39 * *$ & & & & \\
5.empathy & 5.67 & 0.73 & 0.10 & 0.07 & $0.43^{* *}$ & $0.56^{* *}$ & & & & \\
6.distributive & 5.06 & 1.19 & 0.029 & 0.04 & $0.52^{* *}$ & $0.22^{* *}$ & $0.29^{* *}$ & & & \\
justice & 5.61 & 1.13 & $0.11^{*}$ & -0.07 & $0.12^{*}$ & 0.10 & $0.14^{*}$ & $0.16^{* *}$ & & \\
7.performance & 5.56 & 0.75 & -0.11 & -0.04 & 0.00 & $0.33^{* *}$ & $0.28^{* *}$ & $0.20^{* *}$ & $0.37^{* *}$ & \\
8.OCB & 5.25 & 0.96 & -0.10 & -0.04 & 0.11 & $0.28^{* *}$ & $0.28^{* *}$ & $0.19^{* *}$ & $0.26^{* *}$ & $0.67^{* *}$ \\
9.volunteering & 5
\end{tabular}

Note: $\mathrm{N}=314$. SRHRM = socially responsible human resource management. ${ }^{*} p<0.05 ;{ }^{* *} p<0.01 ;{ }^{* * *} p<0.001$.

Table 2 shows the hypothesized seven-factor model fit the data well, $\chi 2=1485, \mathrm{df}=644$, comparative fit index $(\mathrm{CFI})=0.89$, Tucker-Lewis index $(\mathrm{TLI})=0.88$, root-mean-square error of approximation (RMSEA) $=0.06, p<0.001$, and all factor loadings were significant. Comparing the seven-factor model with several alternative models revealed that the seven-factor model fit the data considerably better than did any of the alternative models as shown in the Table 2. The findings supported the discriminant validity of these measures. Furthermore, we conducted a Harman's single-factor test of major variables in this study and found eight factors were extracted with eigenvalue greater than 1, the accumulated amount of explanatory variance was $68.33 \%$, and the largest factor did not account for a majority of the variance $(24.91 \%)$, suggesting that common method variance not be a pervasive problem.

Table 2. Confirmatory factor analyses of the primary study's variables.

\begin{tabular}{ccccccc}
\hline Model & $\chi^{2}$ & $\mathbf{d f}$ & $\boldsymbol{\chi} \mathbf{2} \mathbf{d f}$ & $\mathbf{C F I}$ & TFI & RMSEA \\
\hline Seven factors & 1485.00 & 644 & 2.31 & 0.89 & 0.88 & 0.064 \\
Six factors & 1651.20 & 650 & 2.54 & 0.86 & 0.85 & 0.070 \\
Five factors & 2311.43 & 655 & 3.53 & 0.77 & 0.76 & 0.090 \\
Four factors & 2520.50 & 659 & 3.82 & 0.75 & 0.73 & 0.095 \\
Three factors & 3345.51 & 662 & 5.66 & 0.58 & 0.56 & 0.122 \\
Two factors & 4253.19 & 664 & 6.41 & 0.51 & 0.48 & 0.131 \\
One factor & 6151.86 & 682 & 9.02 & 0.25 & 0.23 & 0.160 \\
\hline
\end{tabular}

Note: Six factors: SRHRM; prosocial identity and empathy combined; distributive justice; task performance; OCB; volunteering. Five factors: SRHRM and distributive justice combined; prosocial identity and empathy combined; task performance; OCB; volunteering. Four factors: SRHRM and distributive justice combined; prosocial identity and empathy combined; task performance; $\mathrm{OCB}$ and volunteering combined. Three factors: SRHRM and distributive justice combined; prosocial identity, empathy and task performance combined; OCB and volunteering combined. Two factors: SRHRM, distributive justice, prosocial identity and empathy combined; task performance, OCB and volunteering combined. One factor: all variables combined.

In testing Hypothesis 1, as shown in Table 3, after controlling for employee gender and age, SRHRM was positively related to prosocial identity $(b=0.32, p<0.001)$, supporting Hypothesis 1 .

Hypothesis 2 predicts that prosocial identity will mediate the positive relationship between SRHRM and task performance, OCB. As shown in Table 3, prosocial identity was positively related to $\mathrm{OCB}(\mathrm{b}=0.32, \mathrm{SE}=0.09, p<0.001)$, and volunteering $(\mathrm{b}=0.26, \mathrm{SE}=0.09, p<0.001)$, but not task performance $(b=0.13, n s)$. Thus hypotheses $2 b$ and $2 c$ were supported.

We further tested the mediation effects using path analysis with bootstrapped, bias corrected $95 \%$ confidence intervals (CIs; [106]). The indirect effects of SRHRM on OCB (indirect effect $=0.11,95 \% \mathrm{CI}$ $[0.05,0.18]$ ) and volunteering (indirect effect $=0.09,95 \%$ CI $[0.04,0.15]$ ) via prosocial identity were positive and significant, supporting Hypotheses $3 \mathrm{~b}$ and $3 \mathrm{c}$. 
Regarding Hypothesis 4, results (see Table 3) showed that after controlling for employee gender and age, SRHRM was positively related to empathy $(b=0.28, p<0.001)$. As for Hypothesis 5 , empathy was positively related to OCB $(b=0.23, \mathrm{SE}=0.10, p<0.05)$ and volunteering $(b=0.25$, $\mathrm{SE}=0.09, p<0.001)$, but not task performance $(\mathrm{b}=0.11, \mathrm{~ns})$. Therefore, Hypotheses $4,5 \mathrm{~b}$ and $5 \mathrm{c}$ were supported. In line with the findings, we then found that a strong indirect effect from SRHRM on OCB via empathy of $0.07, \mathrm{SE}=0.04, p<0.05$, with a $95 \% \mathrm{CI}$ of $[0.02,0.14]$. The indirect effect of SRHRM on volunteering via empathy was $0.07, \mathrm{SE}=0.03, p<0.05$, with a $95 \% \mathrm{CI}$ of $[0.03,0.14]$, thus supporting Hypotheses $6 \mathrm{~b}$ and $6 \mathrm{c}$.

Table 3. Mplus analysis results (coefficients and standard error).

\begin{tabular}{cccccc}
\hline Variable & Identity & Empathy & Performance & OCB & Volunteering \\
\hline Gender & $-0.03(0.08)$ & $0.07(0.08)$ & $0.20(0.12)$ & $-0.21(0.08)$ & $-0.23(0.10)$ \\
Age & $0.00(0.01)$ & $0.01(0.01)$ & $-0.02(0.02)$ & $-0.01(0.01)$ & $-0.01(0.01)$ \\
SRHRM & $0.32^{* * *}(0.07)$ & $0.28^{* * *}(0.08)$ & $-0.10(0.11)$ & $-0.02(0.06)$ & $-0.06(0.06)$ \\
Justice & $0.04(0.06)$ & $0.08(0.07)$ & & & \\
SRHRM $\times$ justice & $0.12 *(0.05)$ & $0.10^{*}(0.05)$ & & & \\
Identity & & & $0.06(0.13)$ & $0.26^{* *}(0.09)$ & $0.32^{* *}(0.10)$ \\
Empathy & & & $0.11(0.13)$ & $0.25^{* *}(0.10)$ & $0.22^{*}(0.10)$ \\
\hline
\end{tabular}

Hypothesis 7a proposes that distributive justice moderates the relationship between SRHRM and prosocial identity. As shown in Table 3, SRHRM and distributive justice interacted to predict prosocial identity $(b=0.12, \mathrm{SE}=0.05, p<0.05)$. Table 3 shows SRHRM had a stronger positive relationship with prosocial identity when distributive justice was high. This supports Hypothesis 7a. The simple slope test is $0.34, \mathrm{t}=7.14, p<0.00$ for higher distributive justice and $0.18, \mathrm{t}=3.27, p<0.01$ for lower distributive justice.

Similarly, we tested Hypothesis $7 \mathrm{~b}$ with the same steps used in Hypothesis 7a. As shown in Table 3, SRHRM and distributive justice interacted to predict empathy ( $\mathrm{b}=0.10, \mathrm{SE}=0.05, p<0.05$ ). Table 3 shows SRHRM had a stronger positive relationship with empathy when distributive justice was high. Thus Hypothesis $7 \mathrm{~b}$ is supported. The simple slope test is $0.35, \mathrm{t}=6.39, p<0.00$ for higher distributive justice and $0.19, \mathrm{t}=3.40, p<0.01$ for lower distributive justice.

\section{Discussion}

This study examined whether, why and on what circumstances SHRMR may foster employees' organizational performance and social performance. According to the results in Table 3, we find that SRHRM, as a type of strategic human resources management designed to move CSR into managerial practice by engaging employees, has a positive relationship with employees' OCB and volunteering but not task performance through the cognitive path-prosocial identity and affective path-empathy.

Particularly, the indirect effect from SRHRM on OCB via empathy is $0.07, \mathrm{SE}=0.04, p<0.05$, with a $95 \% \mathrm{CI}$ of $[0.02,0.14]$ and the indirect effect of SRHRM on volunteering via empathy was $0.07, \mathrm{SE}=0.03$, $p<0.05$, with a $95 \%$ CI of $[0.03,0.14]$. Further, the results suggest that the strength of the relationship between perceived SRHRM on OCB and volunteering via the cognitive and affective path is moderated by distributive justice ( $\mathrm{b}=0.12, \mathrm{SE}=0.05, p<0.05$ ). To sum up, empirical findings have basically proved the mediation effects of prosocial identity and empathy, the moderation effects of distributive justice between SRHRM and employee performance (OCB, volunteering, not task performance). Just as we describe below, these findings offer several implications for research and practice.

\subsection{Theoretical Implication}

This study contributes to the SHRM literature broadly by integrating the elements of social responsibility into HRM. SHRM has long been conceived as responsible for humanistic and social concerns in addition to adding values to organizations. Just as Wright and Mcmahan [113] have appealed that SHRM should create a win-win outcome for organizations and their multiple stakeholders 
through better alignment with the mission and strategic direction of the organization. Hence, SRHRM is proposed to address the calling by incorporating social responsibility values into strategic human resource management $[13,21,22]$. Specifically, this study contributes to the SRHRM literature in several ways.

Firstly, the present research contributes to SRHRM literature by exploring whether SRHRM can achieve a win-win outcome between organization and society. That is, whether SRHRM can promote organizational performance and social performance. Despite that previous research has examined the benefit of SRHRM on organization, such as task performance, extra helping behavior [13], commitment [14], OCB [114], few attempts have been made to examine whether SRHRM can lead to social benefits as well. Taking a balanced perspective, our research extends the scope of SRHRM's consequences, and provides empirical support by considering employees' task performance and $\mathrm{OCB}$ directed to organization and volunteering directed to society. Interestingly, our results show that employees' perceived SRHRM is linked to OCB and volunteering, but not task performance. This finding confirms Bergeron's [115] theoretical arguments that time and resources employees allocate to OCB may come at the expense of task performance. Scholars in the prosocial behavior area have expressed the same concern that investments of time and energy can undercut task performance, leading to negative ramifications for employees' careers [47,116]. One of the underlying reasons may be that prosocial behaviors such as $\mathrm{OCB}$, volunteering to distract an employee from work and even "become a burden or outweigh one's motivation to fulfill more important job responsibilities" [50]. Just as Rapp and his colleagues [117] have noted that boundary condition such as time management skills should be identified to maximize the positive impact of "good thing".

By doing so, we also contribute to OCB literature by identifying organizational practices such as SRHRM as a crucial driven force for employees OCBs. This complements previous research by indicating that not only the care and responsibility for employees but also care for society encourage employees' OCB. In the same vein, we advance volunteering literature by identifying SRHRM as the very antecedents. Together, this insight advances our understanding of the consequences of SRHRM on both organization and society.

Secondly, this study identifies the cognitive and affective mechanisms through which SRHRM improves employees' organizational performance and social performance. Previous researchers have primarily focused on either cognitive mechanism (e.g., organizational identification) or affective mechanism (e.g., commitment) on the effects of SRHRM [14]. By contrast, our research combines the two by integrating identity theory and affective events theory, which complements each other in important ways. Specifically, identity theory contends that contextual context such as organization practices will influence and shape one's new self which in turn guides subsequent behaviors [118]. Affective events theory explicitly acknowledges that work events provoke emotional reactions that influence subsequent behavior and attitudes [20]. The integration of these two theories draws a more comprehensive picture of how SRHRM affects employees through both cognitive and affective paths.

Thirdly, our study introduces distributive justice as an important moderator of the association between SRHMR and employee outcomes. Prior research has found that the contextual factors such as POS and cooperative climate [13] are the boundary condition for the influence of SRHRM, ignoring a more vitally related issue, that is justice. Justice has long been a critical topic entangled in CSR literature since, at their cores, justice and CSR share a common base of fair and ethical treatment to others $[2,15,119]$. Here, justice issues, especially the distributive justice is considered in our study. Based on the justice theories, our research has indicated that employees who have high distributive justice perception are more likely to be influenced by SRHRM via both cognitive and affective process. Thus our study takes a step towards specifying the boundary condition the influence of SRHRM.

In addition, this research contributes to CSR literature by answering the previous call of bridging the macro concept of CSR with micro research in organizational HRM and OB domain [1]. While recent years have witnessed an interest diverting from macro and institutional levels to micro and individual level in CSR research, more efforts should be made to deeply understand how employees react 
psychologically, attitudinally and behaviorally to CSR. After all, it is the employees' involvement and support that heavily determine the successful implementation of CSR policies and practices. Instead of merely examining the influence of CSR on employees, this research takes a step further by investigating employees' response to organizational human resource management advocating CSR initiatives through both cognitive and affective mediating mechanisms. This leads to our second contribution of bridging the significant gap between CSR theory and practice. While corporations are forging ahead with CSR, at the same time, they are struggling with implementing CSR [120]. By integrating the HRM and CSR literature, our research firmed the underexplored construct, the SRHRM, which is targeted to put CSR values into managerial practices with the HRM functions such as recruitment, training. Importantly, this research puts forward and tests a dual-path mediation model to unveil the processes why SRHRM can engage employees in CSR initiative like volunteering as well as beneficial organizational outcomes such as OCB. In sum, this research extends the burgeoning movement of bringing CSR values into practice.

Finally, this article also advances existing knowledge about work identity construction in organizations. For several decades, scholars have attached much attention to how one defines himself $[19,34,121,122]$. Based on the framework of Ashforth and his colleagues' identity construction model [28], we depict a comprehensive view of how this caring and helping work identities, namely prosocial identities are constructed during the interplay between organization and employees. Specifically, prosocial identities are initiated through organizational sensenbreaking, sensegiving and accomplished by employees' sensemaking. Within this process, we identify an important kind of organizational practice (i.e., SRHRM) as an important factor in shaping employees' work identities. In addition, we also shed light on the positive influence of work identities on employee outcomes. These steps serve to theoretically and empirically broaden existing knowledge.

\subsection{Practical Implication}

CSR has long been recognized to contribute a lot to social welfare as well as organization's sustainable development. Despite evidence shows that challenges and risks occur during the CSR practices [5], our findings suggest that investments in human resource management aimed at implementing CSR pay off. As to how to motivate employees to support and engage in the implementation of SRHRM, managers should start from the two paths that guide human behavior and decision making (i.e., the cognitive and affective paths).

On the one hand, the organization should play an active role in shaping employees' positive identity, particularly the prosocial identity here. To do so, sensebreaking and sensegiving through organization practices serve as critical means. For example, organization can engage employees in the CSR initiatives persistently through recruiting applicants who have an interest in CSR, training about CSR communication, and connecting performance in CSR to promotion, compensation and appraisal. Furthermore, an organization can also shape employees' new part of self-concept with both intrinsic motivation and extrinsic rewards, such as the implantation of the idea of responsibility, linking material rewards to employee performance in corporate social responsibility. On the other hand, managers should pay much attention to the management of employee emotion in the workplace. It has long been recognized that emotion plays a central role in human behavior in general and positive emotions facilitate a host of benefits, like task performance, OCB and volunteering, demonstrated in the study. Moreover, managers should be noted that an employee's emotion arises from the appraisal of the environmental event. The implementation of organizational policies or actions should make employees perceive self-relevant, worthwhile and capable of handling.

In addition, as has been demonstrated that, distributive justice should capture managers' attention since how employees are treated fairly treated, especially about the rewards, would affect their response to organizational policies. Particularly, when it comes to such organizational actions conveying social concern to broad society, like CSR, it is of significance to ensure the justice inside 
the organization. The findings further imply that to fully motivate employees to respond to SRHRM positively, the organization needs to note organizational distributive justice.

\section{Conclusions}

The purpose of this research is to examine whether SRHRM leads to a win-win situation by contributing to both organizational and social performance. We find that SRHRM positively influences organizational performance such as OCB and social performance such as volunteering via prosocial identity and empathy. Besides, the positive effect of SRHRM will be stronger when distributive justice is high. We hope our findings stimulate additional research on the implementation of CSR in research, theory, and practice.

Nevertheless, this research has several limitations that should be addressed in future research. First, we asked employees to rate the extent to which SRHRM is conducted in their organization. It is important to note that this approach assesses perceptions regarding the conduct of SRHRM rather than the actual practices. While employees' SRHRM perceptions are likely relevant to actual SRHRM, we encourage future research to explore ways to measure both perceived and actual SHRMR, including the degree and effectiveness of the SRHRM practices.

Second, despite that we collected data from multiple sources, some key variables like the OCB and volunteering, prosocial identity and empathy are highly related. To test the common method variance bias, we adopted the partial correlation procedures. After adding the common method factor, the CFI and TLI increase less than 0.1 and the RMSEA decreases less than 0.05, indicating that the common method bias may not be very significant. Multi-waves and multilevel study are encouraged to uncover the rigor effect of SRHRM on employees.

Third, we measured volunteering as the reflection of social performance because it is the most accepted form of the CSR in organization. However, there is a lot of things employees can do to contribute to social performance, such as developing environmentally friendly technology and developing healthier products. Future research can extend the study by taking a more varied perspective of CSR.

Fourth, we only focused on the contextual factors in examining the effect of SRHRM. More refined understanding can be obtained if future research can further identify other individual factors. For example, it would be interesting to explore whether individual employees with specific types of traits (e.g., attribution, traditionality, time orientation) will respond to SRHRM more positively. In addition, although we theoretically validate the endogeneity problem in the Measure section, future research is encouraged to control some variables that determine the dependent variables and independent variables simultaneously (e.g., firm size) to conduct more rigorous research.

Author Contributions: D.S. substantially contributed to the design of the work, and the preparation of the manuscript. E.Z. contributed to the research problem. P.G. provided constructive suggestions to improve the quality of research, edited and codrafted the manuscript.

Acknowledgments: This research was supported by the National Natural Science Foundation of China under grants no. 71772072, 71801104 and 71471074, the National Social Science Foundation of China under grant no. 16ZDA013, and the China Postdoctoral Science Foundation under grants no. 2017M622462.

Conflicts of Interest: This study has no conflict of interest.

\section{References}

1. Aguinis, H.; Glavas, A. What we know and don't know about corporate social responsibility: A review and research agenda. J. Manag. 2012, 38, 932-968. [CrossRef]

2. Aguilera, R.V.; Rupp, D.E.; Williams, C.A.; Ganapathi, J. Putting the S back in corporate social responsibility: A multilevel theory of social change in organizations. Acad. Manag. Rev. 2007, 32, 836-863. [CrossRef]

3. Flammer, C. Corporate social responsibility and shareholder reaction: The environmental awareness of Investors. Acad. Manag. J. 2013, 56, 758-781. [CrossRef] 
4. Korschun, D.; Bhattacharya, C.B.; Swain, S.D. Corporate social responsibility, customer orientation, and the job performance of frontline employees. J. Mark. 2014, 78, 20-37. [CrossRef]

5. Heli, W.; Li, T.; Takeuchi, R.; George, G. Corporate social responsibility: An overview and new research directions. Acad. Manag. J. 2016, 59, 534-544.

6. Vlachos, P.A.; Panagopoulos, N.G.; Rapp, A.A. Feeling good by doing good: Employee CSR-induced attributions, job satisfaction, and the role of charismatic leadership. J. Bus. Ethics 2013, 118, 577-588. [CrossRef]

7. Chun, J.S.; Shin, Y.; Choi, J.N.; Kim, M.S. How does corporate ethics contribute to firm financial performance? The mediating role of collective organizational commitment and organizational citizenship behavior. J. Manag. 2013, 39, 853-877.

8. Jones, D.A.; Willness, C.R.; Madey, S. Why are job seekers attracted by corporate social performance? Experimental and field tests of three signal-based mechanisms. Acad. Manag. J. 2014, 57, 383-404. [CrossRef]

9. Farooq, O.; Rupp, D.; Farooq, M. The multiple pathways through which internal and external corporate social responsibility influence organizational identification and multifoci outcomes: The moderating role of cultural and social orientations. Acad. Manag. J. 2016, 60, 954-985. [CrossRef]

10. Rodell, J.B. Finding meaning through volunteering: Why do employees volunteer and what does it mean for their jobs? Acad. Manag. J. 2013, 56, 1274-1294. [CrossRef]

11. Rupp, D.E.; Shao, R.; Thornton, M.A.; Skarlicki, D.P. Applicants' and employees' reactions to corporate social responsibility: The moderating effects of first-party justice perceptions and moral identity. Pers. Psychol. 2013, 66, 895-933. [CrossRef]

12. Swanson, O. Socially responsible human resource management. Hum. Resour. Manag. Ethics 2006, 1, 3-25.

13. Shen, J.; Benson, J. When CSR is a social norm: How socially responsible human resource management affects employee work behavior. J. Manag. 2016, 42, 1723-1746. [CrossRef]

14. Shen, J.; Jiuhua Zhu, C. Effects of socially responsible human resource management on employee organizational commitment. Int. J. Hum. Resour. Manag. 2011, 22, 3020-3035. [CrossRef]

15. Rupp, D.E.; Wright, P.M.; Aryee, S.; Luo, Y. Organizational justice, behavioral ethics, and corporate social responsibility: Finally the three shall merge. Manag. Organ. Rev. 2015, 11, 15-24. [CrossRef]

16. Duane Hansen, S.; Dunford, B.; Alge, B.; Jackson, C. Corporate social responsibility, ethical leadership, and trust propensity: A multi-experience model of perceived ethical climate. J. Bus. Ethics 2016, 137, 649-662. [CrossRef]

17. Colquitt, J.A.; Conlon, D.E.; Wesson, M.J.; Porter, C.O.L.H.; Ng, K.Y. Justice at the millennium: A meta-analytic review of 25 years of organizational justice research. J. Appl. Psychol. 2001, 86, 425-445. [CrossRef] [PubMed]

18. Dutton, J.E.; Roberts, L.M.; Bednar, J. Pathways for positive identity construction at work: Four types of positive identity and the building of social resources. Acad. Manag. Rev. 2010, 35, 265-293.

19. Ashforth, B.E.; Mael, F. Social identity theory and the organization. Acad. Manag. Rev. 1989, 14, 20-39. [CrossRef]

20. Weiss, H.M.; Cropanzano, R. Affective Events Theory: A Theoretical Discussion of the Structure, Cause and Consequences of Affective Experiences at Work; American Psychological Association: Washington, DC, USA, 1996.

21. Shen, J.; Benson, J. Socially responsible human resource management: A conceptual framework. In Sustainable Business: Theory and Practice of Business under Sustainability Principles; Edward Elgar Publishing: Cheltenham, UK, 2013; pp. 120-136.

22. Shen, J. Developing the concept of socially responsible international human resource management. Int. J. Hum. Resour. Manag. 2011, 22, 1351-1363. [CrossRef]

23. Hong, B.; Li, Z.; Minor, D. Corporate governance and executive compensation for corporate social responsibility. J. Bus. Ethics 2016, 136, 199-213. [CrossRef]

24. Ikram, A.; Li, Z.F.; Minor, D. Csr-Contingent Executive Compensation Contracts; Social Science Electronic Publishing: Rochester, NY, USA, 2017.

25. Lee, K.; Allen, N.J. Organizational citizenship behavior and workplace deviance: The role of affect and cognitions. J. Appl. Psychol. 2002, 87, 131-142. [CrossRef] [PubMed]

26. Tedeschi, J.T.; Felson, R.B. Violence, aggression, and coercive actions. Pers. Psychol. 1994, 49, 499-502.

27. Anderson, C.A.; Bushman, B.J. Human aggression. Annu. Rev. Psychol. 2002, 53, 27-51. [CrossRef] [PubMed] 
28. Ashforth, B.E.; Schinoff, B.S. Identity under construction: How individuals come to define themselves in organizations. Annu. Rev. Organ. Psychol. Organ. Behav. 2016, 3, 111-137. [CrossRef]

29. Brewer, M.B.; Gardner, W. Who is this" We"? Levels of collective identity and self representations. J. Pers. Soc. Psychol. 1996, 71, 83-93. [CrossRef]

30. Sluss, D.M.; Ashforth, B.E. Relational identity and identification: Defining ourselves through work relationships. Acad. Manag. Rev. 2007, 32, 9-32. [CrossRef]

31. Ibarra, H.; Barbulescu, R. Identity as narrative: Prevalence, effectiveness, and consequences of narrative identity work in macro work role transitions. Acad. Manag. Rev. 2010, 35, 135-154.

32. Maitlis, S.; Christianson, M. Sensemaking in organizations: Taking stock and moving forward. Acad. Manag. Ann. 2014, 8, 57-125. [CrossRef]

33. Pratt, M.G. The good, the bad, and the ambivalent: Managing identification among Amway distributors. Admin. Sci. Q. 2002, 45, 456-493. [CrossRef]

34. Grube, J.A.; Piliavin, J.A. Role identity, organizational experiences, and volunteer performance. Pers. Soc. Psychol. Bull. 2000, 26, 1108-1119. [CrossRef]

35. Grant, A.M.; Dutton, J.E.; Rosso, B.D. Giving commitment: Employee support programs and the prosocial sensemaking process. Acad. Manag. J. 2008, 51, 898-918. [CrossRef]

36. Batson, C.D.; Batson, J.G.; Slingsby, J.K.; Harrell, K.L.; Peekna, H.M.; Todd, R.M. Empathic joy and the empathy-altruism hypothesis. J. Pers. Soc. Psychol. 1991, 61, 413-426. [CrossRef] [PubMed]

37. Weick, K.E.; Sutcliffe, K.M.; Obstfeld, D. Organizing and the process of sensemaking. Organ. Sci. 2005, 16, 409-421. [CrossRef]

38. Rodell, J.B.; Booth, J.E.; Lynch, J.W.; Zipay, K.P. Corporate volunteering climate: Mobilizing employee passion for societal causes and inspiring future charitable action. Acad. Manag. J. 2017, 60, 1662-1681. [CrossRef]

39. Gangi, F.; Salerno, D.; Meles, A.; Daniele, L.M. Do corporate social responsibility and corporate governance influence intellectual capital efficiency. Sustainability 2019, 11, 1899. [CrossRef]

40. Swann, W.B.; Pelham, B.W.; Krull, D.S. Agreeable fancy or disagreeable truth? Reconciling self-enhancement and self-verification. J. Pers. Soc. Psychol. 1989, 57, 782-791. [PubMed]

41. Swann, W.B.; Ely, R.J. A battle of wills: Self-verification versus behavioral confirmation. J. Pers. Soc. Psychol. 1984, 46, 1287-1302. [CrossRef]

42. Swann, W.B.; Read, S.J. Self-verification processes: How we sustain our self-conceptions. J. Exp. Soc. Psychol. 1981, 17, 351-372. [CrossRef]

43. Shamir, B. Meaning, self and motivation in organizations. Organ. Stud. 1991, 12, 405-424. [CrossRef]

44. Leary, M.R. Motivational and emotional aspects of the self. Annu. Rev. Psychol. 2007, 58, 317-344. [CrossRef] [PubMed]

45. Van Dyne, L.; Lepine, J.A. Helping and voice extra-role behaviors: Evidence of construct and predictive validity. Acad. Manag. J. 1998, 41, 108-119.

46. Brief, A.P.; Motowidlo, S.J. Prosocial organizational behaviors. Acad. Manag. Rev. 1986, 11, $710-725$. [CrossRef]

47. George, J.M.; Brief, A.P. Feeling good-doing good: A conceptual analysis of the mood at work-organizational spontaneity relationship. Psychol. Bull. 1992, 112, 310-329. [CrossRef] [PubMed]

48. Grant, A.M. Relational job design and the motivation to make a prosocial difference. Acad. Manag. Rev. 2007, 32, 393-417. [CrossRef]

49. Grant, A.M.; Berg, J.M. Prosocial motivation at work: When, why, and how making a difference makes a difference. Oxf. Handb. Online Sch. Res. Rev. 2011, 28-44. [CrossRef]

50. Bolino, M.C.; Grant, A.M. The bright side of being prosocial at work, and the dark side, Too: A review and agenda for research on other-oriented motives, behavior, and impact in organizations. The Acad. Manag. Ann. 2016, 10, 599-670. [CrossRef]

51. Rioux, S.M.; Penner, L.A. The causes of organizational citizenship behavior: A motivational analysis. J. Appl. Psychol. 2001, 86, 1306-1314. [CrossRef]

52. Nason, R.S.; Bacq, S.; Gras, D. A behavioral theory of social performance: Social identity and stakeholder expectations. Acad. Manag. Rev. 2018, 43, 259-283. [CrossRef]

53. Swanson, D.L. Addressing a theoretical problem by reorienting the corporate social performance model. Acad. Manag. Rev. 1995, 20, 43-64. [CrossRef]

54. Wood, D.J. Corporate social performance revisited. Acad. Manag. Rev. 1991, 16, 691-718. [CrossRef] 
55. Rodell, J.B.; Breitsohl, H.; Schröder, M.; Keating, D.J. Employee volunteering: A review and framework for future research. J. Manag. 2016, 42, 55-84. [CrossRef]

56. Boccalandro, B. Mapping Success in Employee Volunteering; Boston College Center for Corporate Citizenship: Boston, MA, USA, 2009.

57. Craig-Lees, M.; Harris, J.; Lau, W. The role of dispositional, organizational and situational variables in volunteering. J. Nonprofit Public Sect. Mark. 2008, 19, 1-24. [CrossRef]

58. Caligiuri, P.; Mencin, A.; Jiang, K. Win-win-win: The influence of company-sponsored volunteerism programs on employees, NGOs, and business units. Pers. Psychol. 2013, 66, 825-860. [CrossRef]

59. Grant, A.M. Giving time, time after time: Work design and sustained employee participation in corporate volunteering. Acad. Manag. Rev. 2012, 37, 589-615. [CrossRef]

60. Swann, W.B.; Griffin, J.J.; Predmore, S.C.; Gaines, B. The cognitive-affective crossfire: When self-consistency confronts self-enhancement. J. Pers. Soc. Psychol. 1987, 52, 881-889. [CrossRef] [PubMed]

61. Clary, E.G.; Snyder, M.; Ridge, R.D.; Copeland, J.T.; Stukas, A.A.; Haugen, J.A.; Miene, P. Understanding and assessing the motivations of volunteers: A functional approach. J. Pers. Soc. Psychol. 1998, 74, 1516-1530. [CrossRef] [PubMed]

62. Grant, A.M. Leading with meaning: Beneficiary contact, prosocial impact, and the performance effects of transformational leadership. Acad. Manag. J. 2012, 55, 458-476. [CrossRef]

63. Pajo, K.; Lee, L. Corporate-sponsored volunteering: A work design perspective. J. Bus. Ethics 2011, 99, 467-482. [CrossRef]

64. Fisher, C.D. Mood and emotions while working: Missing pieces of job satisfaction? J. Organ. Behav. Int. J. Ind. Occup. Organ. Psychol. Behav. 2000, 21, 185-202. [CrossRef]

65. Beedie, C.; Terry, P.C.; Lane, A.M. Distinctions between emotion and mood. Cogn. Emot. 2005, 19, 847-878. [CrossRef]

66. Lamm, C.; Batson, C.D.; Decety, J. The neural substrate of human empathy: Effects of perspective-taking and cognitive appraisal. J. Cogn. Neurosci 2007, 19, 42-58. [CrossRef] [PubMed]

67. Batson, C.D.; Eklund, J.; Chermok, V.L.; Hoyt, J.L.; Ortiz, B.G. An additional antecedent of empathic concern: Valuing the welfare of the person in need. J. Pers. Soc. Psychol. 2007, 93, 65-74. [CrossRef] [PubMed]

68. Davis, M.H. Empathy: A Social Psychological Approach; Routledge: Abingdon-on-Thames, UK, 2018.

69. Atkins, P.W.B.; Parker, S.K. Understanding individual compassion in organizations: The role of appraisals and psychological flexibility. Acad. Manag. Rev. 2011, 37, 524-546. [CrossRef]

70. Goetz, J.L.; Keltner, D.; Simonthomas, E. Compassion: An evolutionary analysis and empirical review. Psychol. Bull. 2010, 136, 351-374. [CrossRef] [PubMed]

71. Gist, M.E. Self-efficacy: Implications for organizational behavior and human resource management. Acad. Manag. Rev. 1987, 12, 472-485. [CrossRef]

72. Bandura, A. Self-efficacy: Toward a unifying theory of behavioral change. Psychol. Rev. 1977, 84, $191-215$. [CrossRef] [PubMed]

73. Weiss, H.; Suckow, K.; Cropanzano, R. Effects of justice conditions on discrete emotions. J. Appl. Psychol. 1999, 84, 786-794. [CrossRef]

74. De Waal, F.B.M. Putting the Altruism Back into Altruism: The Evolution of Empathy. Annu. Rev. Psychol. 2008, 59, 279-300. [CrossRef]

75. Pavey, L.; Greitemeyer, T.; Sparks, P. "I help because I want to, not because you tell me to" empathy increases autonomously motivated helping. Pers. Soc. Psychol. Bull. 2012, 38, 681-689. [CrossRef]

76. Omdahl, B.L.; O'Donnell, C. Emotional contagion, empathic concern and communicative responsiveness as variables affecting nurses' stress and occupational commitment. J. Adv. Nurs. 1999, 29, 1351-1359. [CrossRef] [PubMed]

77. Settoon, R.P.; Mossholder, K.W. Relationship quality and relationship context as antecedents of person- and task-focused interpersonal citizenship behavior. J. Appl. Psychol. 2002, 87, 255-267. [CrossRef] [PubMed]

78. Joireman, J.; Kamdar, D.; Daniels, D.; Duell, B. Good citizens to the end? It depends: Empathy and concern with future consequences moderate the impact of a short-term time horizon on organizational citizenship behaviors. J. Appl. Psychol. 2006, 91, 1307-1320. [CrossRef] [PubMed]

79. Isen, A.M. Some perspectives on positive affect and self-regulation. Psychol. Inq. 2000, 11, 184-187.

80. Estrada, C.A.; Isen, A.M.; Young, M.J. Positive affect facilitates integration of information and decreases anchoring in reasoning among physicians. Organ. Behav. Hum. Decis. Process. 1997, 72, 117-135. [CrossRef] 
81. Muller, A.R.; Pfarrer, M.D.; Little, L.M. A theory of collective empathy in corporate philanthropy decisions. Acad. Manag. Rev. 2014, 39, 1-21. [CrossRef]

82. Marquis, C.; Glynn, M.A.; Davis, G.F. Community isomorphism and corporate social action. Acad. Manag. Rev. 2007, 32, 925-945. [CrossRef]

83. Boezeman, E.J.; Ellemers, N. Volunteering for charity: Pride, respect, and the commitment of volunteers. J. Appl. Psychol. 2007, 92, 771-785. [CrossRef] [PubMed]

84. Andreoni, J. Impure altruism and donations to public goods: A theory of warm-glow giving. Econ. J. 1990, 100, 464-477. [CrossRef]

85. Kamdar, D.; Mcallister, D.J.; Turban, D.B. “All in a day's work”: How follower individual differences and justice perceptions predict OCB role definitions and behavior. J. Appl. Psychol. 2006, 91, 841-855. [CrossRef] [PubMed]

86. Stolinski, A.; Ryan, C.S.; Hausmann, L.R.M.; Wernli, M.A. Empathy, guilt, volunteer experiences, and intentions to continue volunteering among buddy volunteers in an AIDS organization 1. J. Appl. Biobehav. Res. 2007, 9, 1-22. [CrossRef]

87. Rupp, D.E.; Ganapathi, J.; Aguilera, R.V.; Williams, C.A. Employee reactions to corporate social responsibility: An organizational justice framework. J. Organ. Behav. 2006, 27, 537-543. [CrossRef]

88. Folger, R.; Cropanzano, R.; Goldman, B. What is the relationship between justice and morality. Handb. Organ. Justice 2005, 215, 215-245.

89. Folger, R.G.; Cropanzano, R. Organizational Justice and Human Resource Management; Sage: Newcastle, UK, 1998.

90. Colquitt, J.A.; Lepine, J.A.; Piccolo, R.F.; Zapata, C.P.; Rich, B.L. Explaining the justice-performance relationship: Trust as exchange deepener or trust as uncertainty reducer? J. Appl. Psychol. 2012, 97, 1-15. [CrossRef] [PubMed]

91. Adams, J.S. Towards an understanding of inequity. J. Abnorm. Psychol. 1963, 67, 422-436. [CrossRef] [PubMed]

92. Monin, P.; Noorderhaven, N.G.; Vaara, E.; Kroon, D.P. Giving sense to and making sense of justice in postmerger integration. Acad. Manag. J. 2013, 56, 256-284. [CrossRef]

93. Roberson, Q.M.; Colquitt, J.A. Shared and configural justice: A social network model of justice in teams. Acad. Manag. Rev. 2005, 30, 595-607. [CrossRef]

94. Cropanzano, R.; Mitchell, M.S. Social exchange theory: An interdisciplinary review. J. Manag. 2005, 31, 874-900. [CrossRef]

95. Daileyl, R.C.; Kirk, D.J. Distributive and procedural justice as antecedents of job dissatisfaction and intent to turnover. Hum. Relat. 1992, 45, 305-317. [CrossRef]

96. Blodgett, J.G.; Hill, D.J.; Tax, S.S. The effects of distributive, procedural, and interactional justice on postcomplaint behavior. J. Retail. 1997, 73, 185-210. [CrossRef]

97. Greenberg, J. Stealing in the name of justice: Informational and interpersonal moderators of theft reactions to underpayment inequity. Organ. Behav. Hum. Decis. Process. 1993, 54, 81-103. [CrossRef]

98. Ambrose, M.L.; Seabright, M.A.; Schminke, M. Sabotage in the workplace: The role of organizational injustice. Organ. Behav. Hum. Decis. Process. 2002, 89, 947-965. [CrossRef]

99. Christian, J.S.; Christian, M.S.; Garza, A.S.; Ellis, A.P.J. Examining retaliatory responses to justice violations and recovery attempts in teams. J. Appl. Psychol. 2012, 97, 1218-1232. [CrossRef] [PubMed]

100. McShane, L.; Cunningham, P. To thine own self be true? Employees' judgments of the authenticity of their organization's corporate social responsibility program. J. Bus. Ethics 2012, 108, 81-100. [CrossRef]

101. Motowidlo, S.; Van Scotter, J. Evidence that task performance should be distinguished from contextual performance. J. Appl. Psychol. 1994, 79, 475-480. [CrossRef]

102. Williams, L.J.; Anderson, S.E. Job satisfaction and organizational commitment as predictors of organizational citizenship and in-role behaviors. J. Manag. 1991, 17, 601-617. [CrossRef]

103. Farh, J.; Hackett, R.; Liang, J. Individual-level cultural values as moderators of perceived organizational support-employee outcome relationships in China: Comparing the effects of power distance and traditionality. Acad. Manag. J. 2007, 50, 715-729. [CrossRef]

104. Colquitt, J.A.; Rodell, J.B. Justice, trust, and trustworthiness: A longitudinal analysis integrating three theoretical perspectives. Acad. Manag. J. 2011, 54, 1183-1206. [CrossRef]

105. Colquitt, J.A. On the dimensionality of organizational justice: A construct validation of a measure. J. Appl. Psychol. 2001, 86, 386-400. [CrossRef] 
106. Rodell, J.B.; Lynch, J.W. Perceptions of employee volunteering: Is it "credited" or "stigmatized" by colleagues? Acad. Manag. J. 2016, 59, 611-635. [CrossRef]

107. Li, F. Endogeneity in ceo power: A survey and experiment. Invest. Anal. J. 2016, 45, 149-162. [CrossRef]

108. Dang, C.; Li, Z.F.; Yang, C. Measuring firm size in empirical corporate finance. J. Bank. Financ. 2018, 86, 159-176. [CrossRef]

109. Chatman, J.A.; Flynn, F.J. The influence of demographic heterogeneity on the emergence and consequences of cooperative norms in work teams. Acad. Manag. J. 2001, 44, 956-974.

110. Messersmith, J.G.; Patel, P.C.; Lepak, D.P.; Gouldwilliams, J.S. Unlocking the black box: Exploring the link between high-performance work systems and performance. J. Appl. Psychol. 2011, 96, 1105-1118. [CrossRef] [PubMed]

111. Edwards, J.R.; Lambert, L.S. Methods for integrating moderation and mediation: A general analytical framework using moderated path analysis. Psychol. Methods 2007, 12, 1-22. [CrossRef] [PubMed]

112. Klein, A.G.; Moosbrugger, H. Maximum likelihood estimation of latent interaction effects with the LMS method. Psychometrika 2000, 65, 457-474. [CrossRef]

113. Wright, P.M.; Mcmahan, G.C. Exploring human capital: Putting 'human' back into strategic human resource management. Hum. Resour. Manag. J. 2011, 21, 93-104. [CrossRef]

114. Newman, A.; Miao, Q.; Hofman, P.S.; Zhu, C.J. The impact of socially responsible human resource management on employees' organizational citizenship behaviour: The mediating role of organizational identification. Int. J. Hum. Resour. Manag. 2016, 27, 440-455. [CrossRef]

115. Bergeron, D.M. The potential paradox of organizational citizenship behavior: Good citizens at what cost? Acad. Manag. Rev. 2007, 32, 1078-1095. [CrossRef]

116. Grant, A.M. Does intrinsic motivation fuel the prosocial fire? Motivational synergy in predicting persistence, performance, and productivity. J. Appl. Psychol. 2008, 93, 48-58. [CrossRef]

117. Rapp, A.; Bachrach, D.; Rapp, T. The influence of time management skill on the curvilinear relationship between organizational citizenship behavior and task performance. J. Appl. Psychol. 2013, 98, 668-677. [CrossRef] [PubMed]

118. Grant, A.M.; Berg, J.M.; Cable, D.M. Job titles as identity badges: How self-reflective titles can reduce emotional exhaustion. Acad. Manag. J. 2014, 57, 1201-1225. [CrossRef]

119. Rupp, D.E.; Mallory, D.B. Corporate social responsibility: Psychological, person-centric, and progressing. Annu. Rev. Organ. Psychol. Organ. Behav. 2015, 2, 211-236. [CrossRef]

120. Helmig, B.; Spraul, K.; Ingenhoff, D. Under positive pressure: How stakeholder pressure affects corporate social responsibility implementation. Bus. Soc. 2013, 55, 151-187. [CrossRef]

121. Alvesson, M.; Willmott, H. Identity regulation as organizational control: Producing the appropriate individual. J. Manag. Stud. 2002, 39, 619-644. [CrossRef]

122. Stryker, S.; Burke, P.J. The past, present, and future of identity theory. Soc. Psychol. Q. 2000, 63, $284-297$. [CrossRef]

(C) 2019 by the authors. Licensee MDPI, Basel, Switzerland. This article is an open access article distributed under the terms and conditions of the Creative Commons Attribution (CC BY) license (http://creativecommons.org/licenses/by/4.0/). 